\title{
Structural Characterization of Amidinatobismuth(III) Diazides
}

\author{
Benjamin Lyhs, Dieter Bläser, Christoph Wölper, Rebekka Haack, Georg Jansen, and Stephan \\ Schulz*[a]
}

Keywords: Bismuth / Amidinate / Azide / X-ray diffraction

\begin{abstract}
Amidinatobismuth(III) diazides $\mathrm{LBi}\left(\mathrm{N}_{3}\right)_{2}\left(\mathrm{~L}^{1}=\left[t-\mathrm{BuC}(\mathrm{N} i \text {-Pr })_{2}\right] 2\right.$ $\mathrm{L}^{2}=[t$-BuC(NDipp) 2$\left.]\left(\operatorname{Dipp}=2,6-i-\mathrm{Pr}_{2}-\mathrm{C}_{6} \mathrm{H}_{3}\right) 3\right)$ were synthesized in high yields by metathesis reactions of the corresponding halidesubstituted complexes $\mathrm{L}^{1} \mathrm{BiI}_{2} 1$ and $\mathrm{L}^{2} \mathrm{BiCl}_{2}$ with $\mathrm{AgN}_{3}$. 1 - 3 were characterized by elemental analyses, multinuclear NMR $\left({ }^{1} \mathrm{H},{ }^{13} \mathrm{C}\right)$

\footnotetext{
[a] Faculty of Chemistry, University of Duisburg-Essen, 45117 Essen, Germany Fax: + 49 0201-1834635

E-mail: stephan.schulz@uni-due.de

- Supporting information for this article is available on the WWW under http://www.eurjic.org/ or from the author.
}

\author{
and IR spectroscopy as well as by single crystal X-ray \\ diffraction $(2,3)$. \\ (C) WILEY-VCH Verlag GmbH \& Co. KGaA, 69451 \\ Weinheim, Germany, 2009)
}

\section{Introduction}

Binary group 15 azides have been studied over a long period of time. Neutral polyazides of the types $\mathrm{E}\left(\mathrm{N}_{3}\right)_{3}$ and $\mathrm{E}\left(\mathrm{N}_{3}\right)_{5}(\mathrm{P}, \mathrm{As}, \mathrm{Sb})$ as well as ionic polyazides of the types $\left[\mathrm{E}\left(\mathrm{N}_{3}\right)_{4}\right]^{+}(\mathrm{P}, \mathrm{As}, \mathrm{Sb})$, $\left[\mathrm{E}\left(\mathrm{N}_{3}\right)_{4}\right]^{-}(\mathrm{As}, \mathrm{Sb})$ and $\left[\mathrm{E}\left(\mathrm{N}_{3}\right)_{6}\right]^{-}(\mathrm{P}, \mathrm{As}, \mathrm{Sb})$, which are highly endothermic compounds, are not only of pure academic interest but are also viable candidates for HEDM, since the azido group adds nearly $70 \mathrm{kcal} \mathrm{mol}^{-1}$ to the energy content of a molecule. ${ }^{1}$ Unfortunately, structurally characterized complexes are still limited to $\mathrm{As}\left(\mathrm{N}_{3}\right)_{3},{ }^{2} \mathrm{Sb}\left(\mathrm{N}_{3}\right)_{3},{ }^{2,3} \mathrm{As}\left(\mathrm{N}_{3}\right)_{4},{ }^{-4} \mathrm{Sb}\left(\mathrm{N}_{3}\right)_{4},{ }^{-4} \mathrm{Sb}\left(\mathrm{N}_{3}\right)_{5}{ }^{2-,},{ }^{2} \mathrm{P}\left(\mathrm{N}_{3}\right)_{6},{ }^{-6}$ $\mathrm{As}\left(\mathrm{N}_{3}\right)_{6}{ }_{6},{ }^{7} \mathrm{Sb}\left(\mathrm{N}_{3}\right)_{6},{ }^{-5,8}$ and bipyE$\left(\mathrm{N}_{3}\right)_{3}(\mathrm{E}=\mathrm{As}, \mathrm{Sb}) .{ }^{9}$ The same is true for bismuth azides, which have been structurally characterized only very recently by Schulz et al. $\left(\left[\mathrm{Bi}\left(\mathrm{N}_{3}\right)_{4}\right]^{-},{ }^{10}\left[\mathrm{Bi}\left(\mathrm{N}_{3}\right)_{5}\right]^{2-4}\right.$, $\left.\left[\mathrm{Bi}\left(\mathrm{N}_{3}\right)_{6}\right]^{3-}\right),{ }^{10}$ Haiges et al. $\left(\left[\mathrm{Bi}\left(\mathrm{N}_{3}\right)_{5}\right]^{2-9}, \quad\left[(\mathrm{bipy})_{2} \mathrm{Bi}\left(\mathrm{N}_{3}\right)_{5}\right]^{2-,}\right.$, $\left.\left[(\text { bipy })_{2} \mathrm{Bi}\left(\mathrm{N}_{3}\right)_{3}\right]_{2}\right)^{9}$ und by us $\left(\mathrm{py}_{2} \mathrm{Bi}\left(\mathrm{N}_{3}\right)_{3}\right){ }^{3}$ Moreover, a very few organobismuth azides have been reported. $\mathrm{Ph}_{3} \mathrm{Bi}\left(\mathrm{N}_{3}\right)_{2}$ was synthesized almost 80 years ago by the reaction of $\mathrm{Ph}_{3} \mathrm{BiCl}_{2}$ and $\mathrm{NaN}_{3} .^{11}$ It decomposes upon heating up to $100{ }^{\circ} \mathrm{C}$ with subsequent formation of $\mathrm{Ph}_{2} \mathrm{BiN}_{3}$. $\mathrm{Me}_{2} \mathrm{BiN}_{3}$ was synthesized by reaction of $\mathrm{Me}_{3} \mathrm{Bi}$ with $\mathrm{HN}_{3}{ }^{12}$ and structurally characterized ${ }^{13}$ and $\mathrm{Ph}_{3} \mathrm{Bi}(\mathrm{I}) \mathrm{N}_{3}$ was obtained from the reaction of $\mathrm{Ph}_{3} \mathrm{Bi}$ with $\mathrm{IN}_{3} .{ }^{14}$ Very recently, Schulz et al. reported on aryl-substituted mono and diazides, in which the aryl ligand carries a donor sidearm $\left(\left[2\left(\mathrm{Me}_{2} \mathrm{NCH}_{2}\right) \mathrm{C}_{6} \mathrm{H}_{4}\right]\right) \cdot{ }^{15}$

We became recently interested in complexes containing N,N'chelating amidinato ligands of the type $\mathrm{LEX}_{2}(\mathrm{E}=\mathrm{Sb}, \mathrm{Bi} ; \mathrm{X}=\mathrm{F}$, Cl). ${ }^{16}$ Surprisingly, only very few complexes of this type of the heavy group 15 elements, $\mathrm{Sb}$ and $\mathrm{Bi}$, have been structurally characterized prior to our studies, ${ }^{17}$ most likely due to their tendency to form elemental antimony and bismuth under typical metathesis reaction conditions. Antimony difluoride complexes were found to react with $\mathrm{Me}_{3} \mathrm{SiN}_{3}$ with formation of the corresponding diazide complexes in high yields. ${ }^{18}$ We expanded these studies on the corresponding organobismuth diazides and report herein on the synthesis and X-ray crystal structures of an amidinato bismuthdiiodide complex $\mathrm{LBiI}_{2}$ and two amidinatobismuthdiazides $\operatorname{LBi}\left(\mathrm{N}_{3}\right)_{2}$.

\section{Results and Discussion}

The reaction of main group element fluorides with $\mathrm{Me}_{3} \mathrm{SiN}_{3}$ is a convenient route for the synthesis of the corresponding azides. $\mathrm{Me}_{3} \mathrm{SiF}$, whose formation is thermodynamically strongly favored due to the strong Si-F bond, can easily be removed in vacuo. Unfortunately, reactions of $\mathrm{LBiCl}_{2}$ with fluoride transfer reagents and reactions between $\mathrm{BiF}_{3}$ and $\mathrm{Li}$-amidinates failed to give the corresponding fluorides $\mathrm{LBiF}_{2}$. We therefore investigated halide/azide exchange reactions reaction between $\mathrm{LBiX}_{2}(\mathrm{X}=\mathrm{Cl}$, I) and $\mathrm{AgN}_{3}$.

$$
\begin{gathered}
\mathrm{LiL}^{1}+\mathrm{Bil}_{3} \longrightarrow \mathrm{L}^{1} \mathrm{Bi}_{2} \quad \mathbf{L i l} \\
\mathrm{L}^{1} \mathrm{Bil}_{2}+2 \mathrm{AgN}_{3} \longrightarrow \frac{-2 \mathrm{Agl}}{\longrightarrow} \mathrm{L}^{1} \mathrm{Bi}\left(\mathrm{N}_{3}\right)_{2} \quad \mathbf{2} \\
\mathrm{L}^{2} \mathrm{BiCl}_{2}+2 \mathrm{AgN}_{3} \stackrel{-2 \mathrm{Agl}}{\longrightarrow} \mathrm{L}^{2} \mathrm{Bi}\left(\mathrm{N}_{3}\right)_{2} \quad 3 \\
\mathrm{~L}^{1}=\left[t-\mathrm{BuC}(\mathrm{Ni}-\mathrm{Pr})_{2}, \mathrm{~L}^{2}=\left[t-\mathrm{BuC}(\mathrm{NDipp})_{2}\right]\right.
\end{gathered}
$$

Scheme 1. Synthesis of $1-3$.

$\mathrm{L}^{1} \mathrm{BiI}_{2} \mathrm{1}$ was prepared by reaction of $\mathrm{BiI}_{3}$ with $\mathrm{LiL}^{1}$ in $\mathrm{Et}_{2} \mathrm{O}$ according to a procedure as described for the synthesis of the analogous dichloride complexes and isolated in $74 \%$ yield after workup. Reactions of $\mathrm{L}^{1} \mathrm{BiI}_{2}$ and $\mathrm{L}^{2} \mathrm{BiCl}_{2}$ with $\mathrm{AgN}_{3}$ yielded the expected diazide complexes $\mathrm{LBi}\left(\mathrm{N}_{3}\right)_{2}\left(\mathrm{~L}=\mathrm{L}^{1} \mathbf{2}, \mathrm{L}^{2} \mathbf{3}\right)$ in yields higher than $90 \%$. $1-3$ are crystalline solids which decompose starting at $95{ }^{\circ} \mathrm{C}(\mathbf{1}), 185^{\circ} \mathrm{C} \mathrm{(2)} \mathrm{and} 210{ }^{\circ} \mathrm{C}(3)$, respectively. ${ }^{1} \mathrm{H}$ and ${ }^{13} \mathrm{C}$ NMR spectra of $\mathbf{1}-\mathbf{3}$ exhibit the expected resonances due to the amidinate moieties and IR spectra of $\mathbf{2}$ and $\mathbf{3}$ each show strong absorption bands due to the asymmetric N-N-N stretching frequency (2043, 1992 2; 2077, 2042, 2016, $1999 \mathrm{~cm}^{-1}$ 3). Comparable values were observed for antimony diazides ${ }^{18}$ and bismuth diazides. ${ }^{15}$ The expected bands due to the symmetric N-N$\mathrm{N}$ stretching frequency (around $1300 \mathrm{~cm}^{-1}$ ) and the N-N-N deformation mode (around $640 \mathrm{~cm}^{-1}$ ) are overlapped by the 
absorption bands of the amidinato group. In contrast, weak stretching frequencies due to the sum of asymmetric and symmetric stretching frequency $v_{\mathrm{s}} \mathrm{N}_{3}+v_{\mathrm{as}} \mathrm{N}_{3}(3321,32822 ; 3340$ 3) were observed.

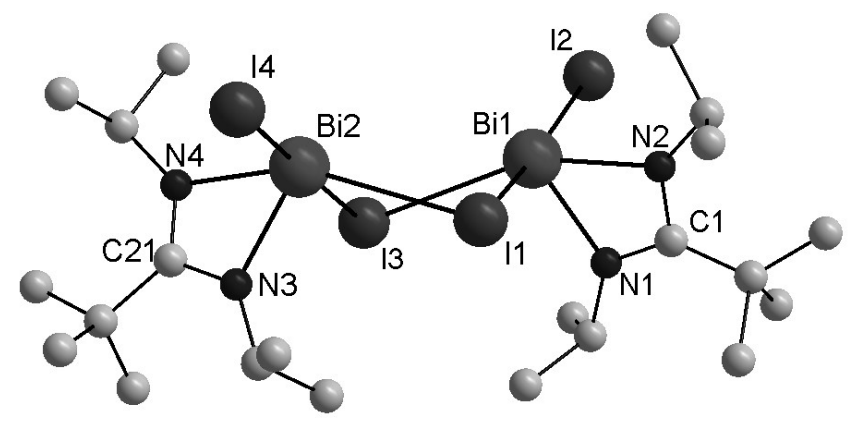

Figure 1. Molecular structure of $\mathrm{L}^{1} \mathrm{BiI}_{2} \mathbf{1}$; Atoms displayed at arbitrary radii. Hydrogen atoms are omitted for clarity. Only the connectivity could be determined reliably due to the poor scattering power of the crystals.

Several attempts to crystallize $\mathbf{1}$ only yielded crystals of poor quality. However, those obtained from a solution in $\mathrm{CHCl}_{3}$ allowed the determination of the connectivity of $\mathbf{1}$. The space group was found to be Pbca. The Bi atoms are each coordinated by one amidinate ligand, one terminal and two bridging iodine atoms, in a distorted square-pyramidal coordination mode. The amidinate moiety serves as $\mathrm{N}, \mathrm{N}^{\prime}$-chelating $\left(\eta^{2}\right)$ four-electron donor ligand as was observed for the dichlorides $\mathrm{LBiCl}_{2}{ }^{16}$ However, structural details of $\mathbf{1}$ can't be discussed due to the poor quality of the crystals.

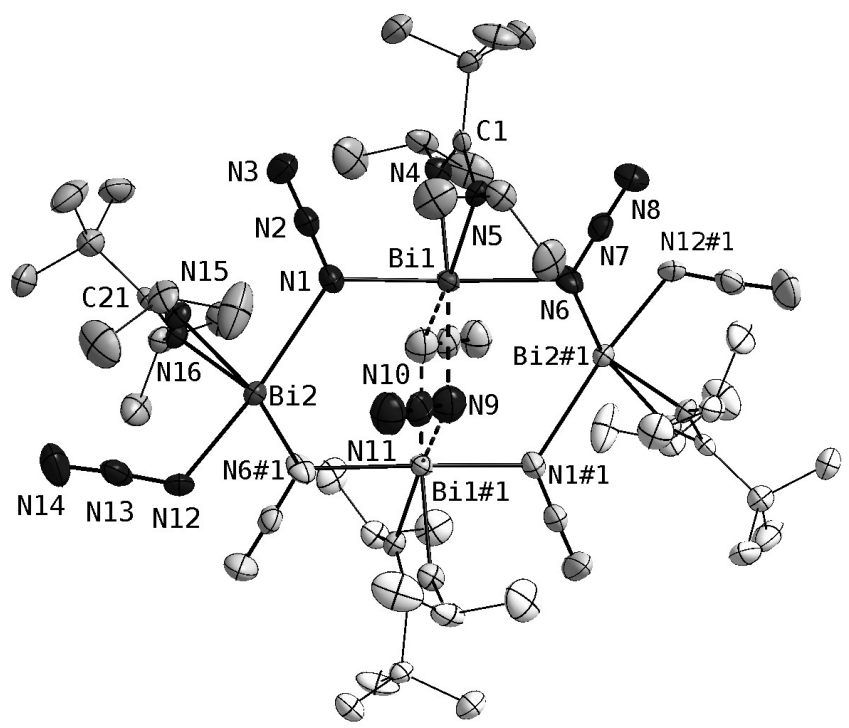

Figure 2. Molecular structure of $\mathrm{L}^{1} \mathrm{Bi}\left(\mathrm{N}_{3}\right)_{2}$ 2; thermal ellipsoids are drawn at the $50 \%$ probability level. Symmetry equivalent atoms depicted in pale colors (\#1:- $\mathrm{x}+1,-\mathrm{y}+1,-\mathrm{z}+1)$. Contacts beyond $2.7 \AA$ are shown in dashed lines. Hydrogen atoms have been omitted for clarity. $\mathrm{Bi}(1)-\mathrm{N}(1) 2.411(7)$ $\mathrm{Bi}(1)-\mathrm{N}(6)$ 2.432(8), $\mathrm{Bi}(1) \cdots \mathrm{N}(9)$ 2.760(9), Bi(2)-N(1) 2.668(7), Bi(2)$\mathrm{N}(6) \# 1 \quad 2.597(8), \mathrm{Bi}(2)-\mathrm{N}(12) 2.265(7), \mathrm{N}(1)-\mathrm{N}(2)$ 1.230(11), N(2)-N(3) $1.138(12), \mathrm{N}(9)-\mathrm{N}(10) 1.161(12), \mathrm{N}(10)-\mathrm{N}(11) 1.171(13), \mathrm{N}(12)-\mathrm{N}(13)$ 1.203(11), N(13)-N(14) 1.156(12); N(1)-Bi(1)-N(6) 172.3(2), N(6)\#1$\mathrm{Bi}(2)-\mathrm{N}(1)$ 98.8(2), Bi(1)-N(1)-Bi(2) 124.5(3), Bi(1)-N(6)-Bi(2)\#1 118.0(3), $\mathrm{N}(8)-\mathrm{N}(7)-\mathrm{N}(6)$ 178.8(9), N(9)-N(10)-N(11) 178.3(11).

Single crystals of 2 were obtained from a solution in $\mathrm{CH}_{2} \mathrm{Cl}_{2}$ after storage at $-30{ }^{\circ} \mathrm{C}$ for $48 \mathrm{~h}$, whereas those of $\mathbf{3}$ were obtained from a $\mathrm{C}_{6} \mathrm{H}_{4} \mathrm{~F}_{2}$ solution at $0{ }^{\circ} \mathrm{C} .2$ crystallizes in the triclinc space group $P$-1. The asymmetric unit, which is located about a centre of inversion, consists of two $\mathrm{Bi}$ atoms, two amidinate ligands and four azide groups (Fig. 2, geometric data given in the caption). Three azide groups show typical N-N bond lengths of covalently-bound azides (av. $\mathrm{N}_{\alpha}-\mathrm{N}_{\beta} 1.20 \AA$, av. $\mathrm{N}_{\beta}-\mathrm{N}_{\gamma} 1.14 \AA$ ), whereas the fourth one (N9-N10-N11) shows almost equidistant $\mathrm{N}_{\alpha}-\mathrm{N}_{\beta}$ and $\mathrm{N}_{\beta}-\mathrm{N}_{\gamma}$ bonds as is typically for ionic azides. The shortest distance from this azide to a $\mathrm{Bi}$ atom is $2.760(9) \AA$. Considering this azide as apparently ionic, this contact can be regarded as a weak attractive interaction rather than a covalent bond, although the distance is within the range of $\mathrm{Bi}-\mathrm{N}$ bonds. ${ }^{29}$ Therefore we will consider any $\mathrm{Bi} \cdots \mathrm{N}$ distance up to $2.7 \AA$ to be a covalent bond. However, this choice is to a certain extent arbitrary and should be scrutinized before applying it to other cases.

2 forms a centrosymmetric eight-membered $\mathrm{Bi}_{4} \mathrm{~N}_{4}$ ring with $\mathrm{N}_{\alpha^{-}}$ bridging azide groups. In addition, two weak interactions between $\mathrm{Bi}(1)$ and $\mathrm{Bi}(1) \#$ and the rather ionic azide moiety $(\mathrm{N}(9)-\mathrm{N}(10)-$ $\mathrm{N}(11)$ ) were observed. Each bismuth atom is further coordinated by one chelating amidinate ligand and $\mathrm{Bi}(2)$ by an additional covalently bound terminal azide group (N(12)-N(13)-N(14)). The $\operatorname{Bi}(1)-\mathrm{N}_{\alpha}$ bonds $(2.411(7) \AA, 2.432(8) \AA)$ of the bridging azides within the eight-membered ring are shorter than the $\mathrm{Bi}(2)-\mathrm{N}_{\alpha}$ bonds (2.668(7) $\AA, 2.597(8) \AA$ ), which should also be considered as covalent bonds according to the different N-N bond lengths within the azide groups, even though a certain ionic contribution is likely. In contrast, the $\mathrm{Bi}(1) \cdots(\mathrm{N} 9)$ and $\mathrm{Bi}(1) \cdots \mathrm{N}(9) \# 1$ bond lengths (2.760(9) $\AA, 2.88(1) \AA)$ indicate a primarily ionic interaction with weak covalent contribution. The coordination number of $\mathrm{Bi}(1)$ is best described as $4+2$ and that of $\operatorname{Bi}(2)$ as 5 . As a consequence, $\mathrm{Bi}(1)$ adopts a slightly distorted octahedral coordination sphere, whereas that of $\mathrm{Bi}(2)$ is best described as distorted squarepyramidal. The sixth ligand completing the octahedron is occupied by $\mathrm{N}(11)$ of the "ionic" azide. However, both the long the $\operatorname{Bi}(2) \cdots \mathrm{N}(11)$ distance of 3.273(9) $\AA$ and the almost equidistant $\mathrm{N}$ $\mathrm{N}$ bond lengths within this azide group do not suggest a covalent $\mathrm{Bi}-\mathrm{N}$ bond. The conformation of the eight-membered ring is comparable to the chair-conformation of a cyclohexane ring. While $\mathrm{N}(1), \mathrm{N}(6), \mathrm{Bi}(1)$ and their symmetry equivalents are placed in a plane (r.m.s. deviation $0.065 \AA$ ), $\operatorname{Bi}(2)$ and its equivalent are above and below this plane, respectively.

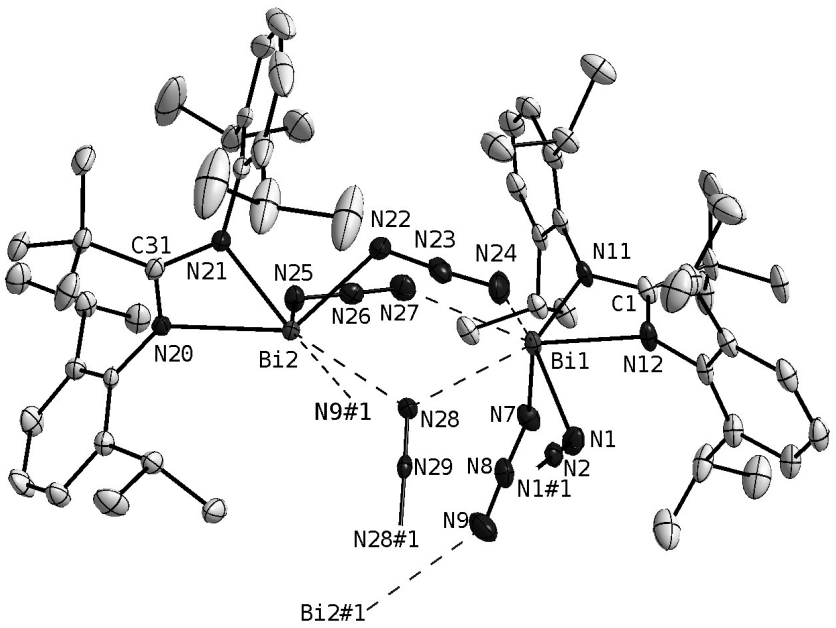

Figure 3. Asymmetric unit of $\mathrm{L}^{2} \mathrm{Bi}\left(\mathrm{N}_{3}\right)_{2} 3$; thermal ellipsoids are drawn at the $50 \%$ probability level. $\mathrm{N}(2)$ and $\mathrm{N}(29)$ occupy special positions (2-fold axis, $\# 1-\mathrm{x}+1, \mathrm{y},-\mathrm{z}+1 / 2)$. Hydrogen atoms and disordered 1,2difluorobenzene have been omitted for clarity. $\mathrm{Bi}(1)-\mathrm{N}(1)$ 2.439(2), $\mathrm{Bi}(1)-$ $\mathrm{N}(7) \quad 2.211(2) ， \quad \mathrm{Bi}(1)-\mathrm{N}(11) \quad 2.344(2) ， \mathrm{~N}(1)-\mathrm{N}(2) \quad 1.178(2) ， \mathrm{~N}(7)-\mathrm{N}(8)$ 
$1.208(3), \mathrm{N}(8)-\mathrm{N}(9) 1.153(3), \mathrm{Bi}(2)-\mathrm{N}(22) 2.287(2), \mathrm{Bi}(2)-\mathrm{N}(25) 2.235(2)$, $\mathrm{N}(22)-\mathrm{N}(23) \quad 1.205(3), \quad \mathrm{N}(23)-\mathrm{N}(24)$ 1.152(3), N(28)-N(29) 1.182(2), $\mathrm{N}(25)-\mathrm{Bi}(2)-\mathrm{N}(22) \quad 87.5(1), \mathrm{N}(1) \# 1-\mathrm{N}(2)-\mathrm{N}(1) \quad 177.4(4), \mathrm{N}(9)-\mathrm{N}(8)-\mathrm{N}(7)$ 174.3(3), N(24)-N(23)-N(22) 176.3(3), N(28)-N(29)-N(28)\#1 179.1(4).

3 crystallizes in the monoclinic space group $C 2 / c$. The asymmetric unit contains two Bi atoms, two $\eta^{2}$-chelating amidinate ligands, three azide groups on general positions and two azide groups on special positions (2-fold axis) as well as a 1,2difluorobenzene molecule disordered over a centre of inversion. The molecular structure of $\mathbf{3}$ is best described as a tetramer, with four $\mathrm{Bi}$ atoms adopting distorted tetrahedral arrangements around an azide group on a special position $(\mathrm{N}(28)-\mathrm{N}(29)-\mathrm{N}(28) \# 1)$. The edges - except for $\mathrm{Bi}(2) / \mathrm{Bi}(2) \# 1$ - of this tetrahedron are bridged by three azide groups on general positions, their symmetry equivalents and the remaining azide group on a special position $(\mathrm{N}(1)-\mathrm{N}(2)-$ $\mathrm{N}(1) \# 1)$. The $\mathrm{Bi}(1) / \mathrm{Bi}(2)$ edge is bridged twice. The bond lengths within the azide groups, which are located on general positions, suggest covalently bound azide groups. This is supported by the finding that the $\mathrm{Bi}-\mathrm{N}_{\alpha}$ bond lengths are within the range of the sum of the covalent radii (bond lengths see figure caption). The connection to the neighboring $\mathrm{Bi}$ atom is established by the $\mathrm{N}_{\gamma}$ atoms of the azides. These are longer than $2.7 \AA(2.985(2)$ to 3.013(3) $\AA$ ) and should be regarded as weak attractive interactions.

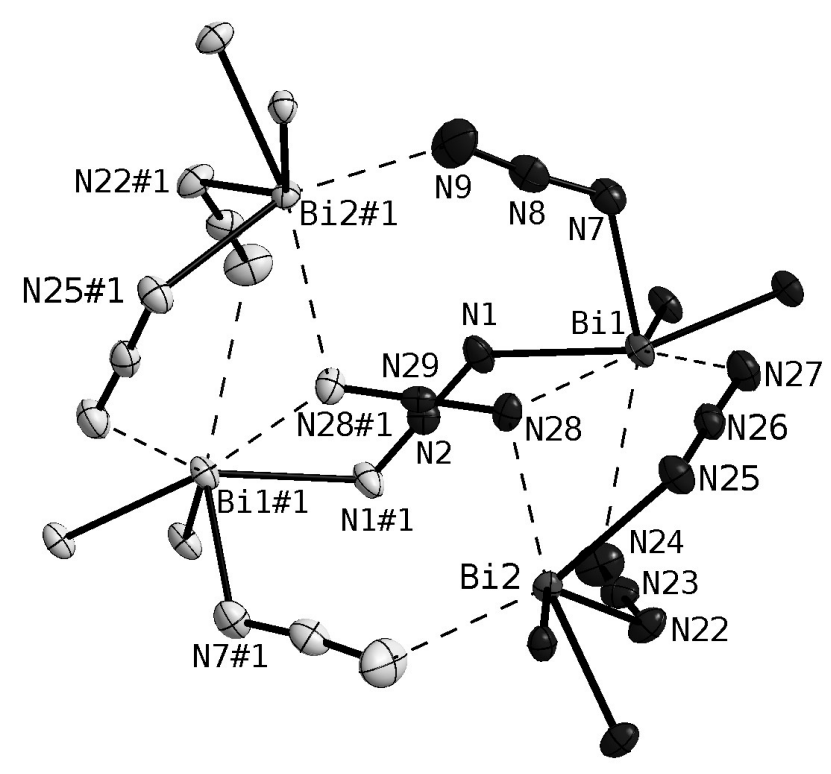

Figure 4. Reduced molecular structure of $\mathrm{L}^{2} \mathrm{Bi}\left(\mathrm{N}_{3}\right)_{2}$ 3; thermal ellipsoids are drawn at the $50 \%$ probability level. Symmetry equivalent atoms are depicted in pale colors $(\# 1-x+1, y,-z+1 / 2)$. $N(2)$ and $N(29)$ occupy special positions (2-fold axis). Contacts beyond $2.7 \AA$ are shown in dashed lines. The amidinate groups have been reduced to the nitrogen atoms for clarity. $\mathrm{Bi}(1) \cdots \mathrm{N}(28) 2.906(2), \mathrm{Bi}(1) \cdots \mathrm{N}(24) 3.013(3), \mathrm{Bi}(1) \cdots \mathrm{N}(27) 2.985(2)$,

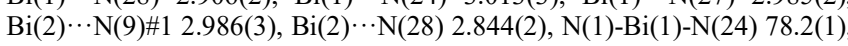
$\mathrm{N}(1)-\mathrm{Bi}(1) \cdots \mathrm{N}(27) \quad 138.4(1), \quad \mathrm{N}(7)-\mathrm{Bi}(1) \cdots \mathrm{N}(24) \quad 154.2(1), \quad \mathrm{N}(7)$ $\mathrm{Bi}(1) \cdots \mathrm{N}(27)$ 87.2(1), N(11)-Bi(1) $\cdots \mathrm{N}(24)$ 120.9(1), N(11)-Bi(1) $\cdots \mathrm{N}(27)$ $85.5(1), \quad \mathrm{N}(12)-\mathrm{Bi}(1) \cdots \mathrm{N}(24) \quad 107.0(1), \quad \mathrm{N}(12)-\mathrm{Bi}(1) \cdots \mathrm{N}(27) \quad 142.3(1)$, $\mathrm{N}(22)-\mathrm{Bi}(2) \cdots \mathrm{N}(28) \quad 80.9(1), \quad \mathrm{N}(22)-\mathrm{Bi}(2) \cdots \mathrm{N}(9) \# 1 \quad 82.5(1), \quad \mathrm{N}(25)-$

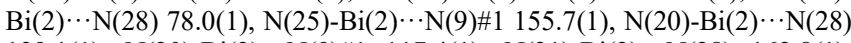

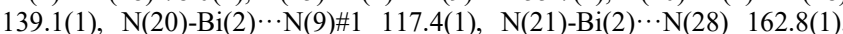
$\mathrm{N}(21)-\mathrm{Bi}(2) \cdots \mathrm{N}(9) \# 1 \quad 102.2(1), \quad \mathrm{Bi}(1) \cdots \mathrm{N}(28) \cdots \mathrm{Bi}(2) \quad 123.3(1)$, $\mathrm{Bi}(1) \cdots \mathrm{N}(28)-\mathrm{N}(29) \quad 124.5(2), \quad \mathrm{Bi}(2) \cdots \mathrm{N}(28)-\mathrm{N}(29) \quad 107.5(2), \quad \mathrm{N}(8)-$ $\mathrm{N}(9) \cdots \mathrm{Bi}(2) \# 1 \quad 141.0(2), \quad \mathrm{N}(26)-\mathrm{N}(27) \cdots \mathrm{Bi}(1) \quad 121.2(2), \quad \mathrm{N}(23)-$ $\mathrm{N}(24) \cdots \mathrm{Bi}(1) 101.5(2)$.

In case of the first azide group located on the special position (N(1)-N(2)-N(1)\#1), however, the bonding situation is less obvious. The N-N bond lengths within this azide group, which are necessarily equal, point to an ionic nature, whereas the $\mathrm{N}(1)-\mathrm{Bi}(1)$ distance of 2.439(2) A suggests a rather weak covalent bond. Since the mean value of the different bond lengths in covalently bound azides is equal to the bond length of ionic azides, a disorder of a covalently bound azide over the special position can be considered. However, in this case two positions for $\mathrm{N}_{\beta}$ or, due to the proximity of these positions, a large, elongated thermal ellipsoid orientated parallel to the N-N bonds should be found. This was not observed, but the crystal did not yield the high resolution data necessary to investigate the electron density in detail. The available crystallographic data alone cannot elucidate the nature of these bonds. The second azide group on a special position $(\mathrm{N}(28)-\mathrm{N}(29)-$ $\mathrm{N}(28) \# 1)$ unexceptionally shows $\mathrm{Bi} \cdots \mathrm{N}$ distances longer than 2.7 $\AA$, indicating a rather ionic interaction. Taking all covalent Bi-N bonds and weak Bi-N interactions into account, the coordination number of $\mathrm{Bi}(1)$ is $4+3$, resulting in a distorted pentagonal bipyramidal coordination sphere with $\mathrm{N}(7)$ and $\mathrm{N}(24)$ in the axial positions and two of the long contacts in the equatorial plane. The coordination number of $\mathrm{Bi}(2)$ is $4+2$, leading to a distorted octahedral environment.

Comparing the structural parameters observed for $\mathbf{2}$ and $\mathbf{3}$, two main influences on the solid state structures become obvious: the tendency of the $\mathrm{Bi}$ atom to enlarge its coordination sphere and the steric demand of the amidinate ligand. The larger size of the Dipp groups in $\mathbf{3}$ prevents the formation of an $\mathrm{N}_{\alpha}$ bridged tetramer as was observed for $\mathbf{2}$. Instead, the intermediate $\mathrm{Bi}-\mathrm{N}$ bond lengths are elongated, indicating rather weak interactions (see $\mathrm{Bi}-\mathrm{N}$ bond lengths histogram in SI). The formation of these weak attractive interactions involving the $\mathrm{N}_{\gamma}$ atoms of the azide groups results in an enlarged coordination number of the $\mathrm{Bi}$ atoms. In addition, the enlarged size of the tetrameric cage-like unit in $\mathbf{3}$ now allows the ionic azides $(\mathrm{N}(28)-\mathrm{N}(29)-\mathrm{N}(28) \# 1)$ to adopt a position inside the tetrameric structure. In contrast, the ionic azide groups in $2(\mathrm{~N}(9)$ $\mathrm{N}(10)-\mathrm{N}(11)$ ) rather adopt bridging positions between two $\mathrm{Bi}$ atoms in 2. In $\left[2-\left(\mathrm{Me}_{2} \mathrm{NCH}_{2}\right) \mathrm{C}_{6} \mathrm{H}_{4}\right]_{2} \mathrm{Bi}\left(\mathrm{N}_{3}\right)^{15}$ the steric demand is increased even further and consequently no secondary interactions between $\mathrm{Bi}$ and any donor atom can be established. In contrast, $\mathrm{N}_{\alpha^{-}}$ bridged chain polymers were observed for $\mathrm{Me}_{2} \mathrm{BiN}_{3}{ }^{30}$ and $\mathrm{py}_{2} \mathrm{Bi}\left(\mathrm{N}_{3}\right)_{3},{ }^{3}$ containing sterically less demanding organic groups.

Theoretical calculations were performed in order to investigate the structure of $\mathbf{2}$, in particular the nature of the "ionic" azide group $((\mathrm{N}(9)-\mathrm{N}(10)-\mathrm{N}(11))$. Starting from the crystal structure 2, we optimized the gas phase structure (2') on the BP+D/QZVP level of dispersion corrected density functional theory without symmetry constraints. The optimized structure $\left(2^{\prime}\right)$, which is qualitatively in total agreement with the solid state structure (2), also displays $C_{i-}$ symmetry. The main differences concern the location and internal structure of the "ionic" azides, which according to the calculations should be also described as covalently bound. The N(9)-N(10) $(1.208 \AA)$ and $\mathrm{N}(10)-\mathrm{N}(11)(1.166 \AA)$ bond lengths differ by roughly $4 \mathrm{pm}$, similar to the bridging azide groups, in which the differences amount to $6 \mathrm{pm}$. Furthermore, they are dislocated by 0.1-0.2 $\AA$ with respect to the neighboring $\mathrm{Bi}$ atoms $(\mathrm{Bi}(1)-\mathrm{N}(9 \# 1)$ $2.599 \AA ; \mathrm{Bi}(1)-\mathrm{N}(9) 2.876 \AA)$. Partial charges of the optimized structure were obtained through natural population analysis (NPA). According to the NPA, the charges on the $\mathrm{Bi}$ atoms are +1.88 $(\mathrm{Bi}(1))$ and $+1.73 e(\mathrm{Bi}(2))$, respectively. The total charges on the azide ligands are almost identical, ranging from -0.69 to $-0.73 e$. In addition, the partial charge distributions within the azide groups are also very similar as summarized in table 2 . According to these results, there is no indication that the bonding situation within the different azide ligands is really different. Since the crystal structure in contrast to the optimized structure shows almost equidistant N-N bond lengths within the $\mathrm{N}(9)-\mathrm{N}(10)-\mathrm{N}(11)$ azide group, we 
checked whether this is also reflected in an NPA carried out at exactly the same level of theory but using the crystal structure as geometrical input. Despite the relatively slight changes of the central geometrical parameters, the crystal structure consistently displays higher charges on the $\mathrm{Bi}$ atoms and the azide groups, indicating an overall higher ionic character. The Bi atoms carry high positive charges of $+2.85(\mathrm{Bi}(1))$ and $+2.80 e(\mathrm{Bi}(2))$, respectively, and the total charges of the azide groups range from 1.07 to $-1.15 e$. Consistently, the $\mathrm{N}_{\alpha}$ and $\mathrm{N}_{\gamma}$ atoms carry charges of about -1 e and the $\mathrm{N}_{\beta}$ atoms are positively charged (roughly +0.9 e) Again, NPA does not indicate that the N(9)-N(10)-N(11) azide group has a different electronic character compared to the other azide groups, despite the difference in the internal N-N bond lengths.

Table 1. NPA charges of $\mathbf{2}$ and $\mathbf{2}$.

\begin{tabular}{lll}
\hline & $\mathbf{2}$ & $\mathbf{2}$ \\
\hline Bi1 & +2.85 & +1.88 \\
$\mathbf{B i 2}$ & +2.80 & +1.73 \\
$\mathbf{N 1}$ & -1.01 & -0.65 \\
$\mathbf{N 2}$ & +0.87 & +0.16 \\
$\mathbf{N 3}$ & -0.93 & -0.21 \\
N6 & -0.95 & -0.70 \\
N7 & +0.82 & +0.16 \\
N8 & -1.02 & -0.15 \\
N9 & -0.92 & -0.60 \\
N10 & +0.91 & +0.12 \\
N11 & -1.08 & -0.24 \\
\hline
\end{tabular}

\section{Conclusions}

Two multinuclear $\mathrm{Bi}$ diazides containing N,N'-chelating amidinate groups have been synthesized and fully characterized including X-ray diffraction. The structural parameters of the azide groups in 2 differ in the solid state, indicating a different bonding situation, but gas phase calculations on the DFT level of theory did not show significant differences. Even though the absolute charges within the experimental and optimized structures differ considerably, the electronic nature of the various azide groups within each structure is comparable.

\section{Experimental Section}

General Procedures. All manipulations were performed under an argon atmosphere using standard Schlenk techniques. Solvents were dried over $\mathrm{Na} / \mathrm{K}\left(\mathrm{Et}_{2} \mathrm{O}\right)$ and $\mathrm{CaH}_{2}\left(\mathrm{CH}_{2} \mathrm{Cl}_{2}, \mathrm{CHCl}_{3}, \mathrm{C}_{6} \mathrm{H}_{4} \mathrm{~F}_{2}\right)$ and degassed prior to use. $\mathrm{LBiCl}_{2}{ }^{16}$ and $\mathrm{AgN}_{3}{ }^{19}$ were prepared according to literature methods. ${ }^{1} \mathrm{H}$ and ${ }^{13} \mathrm{C}\left\{{ }^{1} \mathrm{H}\right\}$ NMR spectra were recorded on a Bruker Avance 300 spectrometer and are referenced to internal $\mathrm{CDCl}_{3}\left({ }^{1} \mathrm{H}: \delta=7.26 ;{ }^{13} \mathrm{C}: \delta=77.0\right)$ or $\mathrm{CD}_{2} \mathrm{Cl}_{2}$ $\left({ }^{1} \mathrm{H}: \delta=5.32 ;{ }^{13} \mathrm{C}: \delta=53.84\right)$. IR spectra were recorded on a ALPHA-T FTIR spectrometer equipped with a single reflection ATR sampling module. Melting points were measured in sealed capillaries and were not corrected. Elemental analyses were performed at the Elementaranalyse Labor of the University of Essen.

Caution. Covalent azides are potentially hazardous and can decompose explosively under various conditions! Even though $\mathbf{2}$ and $\mathbf{3}$ in our hands did not show any sign of shock and heat sensitivity, appropriate safety precautions (safety shields, face shields, leather gloves, protective clothing) should be taken, particularly when dealing with larger quantities.

$\mathbf{L}^{1} \mathbf{B i I}_{2}$ 1: Solid $\left.\mathrm{LiL}^{1}\left(\mathrm{~L}^{1}=t \text {-BuC(Ni-Pr }\right)_{2}\right)(1.00 \mathrm{~g}, 5.26 \mathrm{mmol})$ was slowly added within $3 \mathrm{~h}$ to a suspension of $\mathrm{BiI}_{3}(3.10 \mathrm{~g}, 5.26 \mathrm{mmol})$ in $150 \mathrm{~mL}$ of $\mathrm{Et}_{2} \mathrm{O}$ at $-78^{\circ} \mathrm{C}$, stirred for $1 \mathrm{~h}$ and then warmed to ambient temperature over a period of $12 \mathrm{~h}$. The resulting precipitate was filtered and extracted two times with $\mathrm{CHCl}_{3}(40 \mathrm{~mL})$. The solvent was evaporated in vacuum, yielding 1 as an orange solid.

Yield $2.51 \mathrm{~g}$ (3.89 mmol, 74\%). Melting point: decomposition above $95{ }^{\circ} \mathrm{C}$ Elemental Analysis $\mathrm{C}_{11} \mathrm{H}_{23} \mathrm{~N}_{2} \mathrm{BiI}_{2}(646.11 \mathrm{~g} / \mathrm{mol})$ : found (calcd): $\mathrm{H}, 3.55$ (3.59); C, 20.65 (20.45); N, 4.41 (4.34) \%. ${ }^{1} \mathrm{H}$ NMR (300 MHz, $\mathrm{CDCl}_{3}$, $\left.25^{\circ} \mathrm{C}\right): \delta 1.39\left(\mathrm{~d},{ }^{3} \mathrm{~J}_{\mathrm{HH}}=6.2 \mathrm{~Hz}, 12 \mathrm{H}, \mathrm{CH}\left(\mathrm{CH}_{3}\right)_{2}\right), 1.50(\mathrm{~s}, 9 \mathrm{H}, t-\mathrm{Bu}), 5.95$ (sep, $\left.{ }^{3} \mathrm{~J}_{\mathrm{HH}}=6.2 \mathrm{~Hz}, 2 \mathrm{H}, \mathrm{CH}\left(\mathrm{CH}_{3}\right)_{2}\right) .{ }^{13} \mathrm{C} \mathrm{NMR}\left(75 \mathrm{MHz}, \mathrm{CDCl}_{3}, 25{ }^{\circ} \mathrm{C}\right): \delta$ $24.7\left(\mathrm{CHMe}_{2}\right), 29.9\left(\mathrm{CMe}_{3}\right), 49.6\left(\mathrm{CHMe}_{2}\right), 51.7\left(\mathrm{CMe}_{3}\right), 177.0\left(\mathrm{CN}_{2}\right)$. IR: v $3966(\mathrm{~s}), 2929(\mathrm{~m}), 2871(\mathrm{w}), 2118(\mathrm{w}), 1617(\mathrm{w}), 1594(\mathrm{~m}), 1451(\mathrm{~m})$, 1405 (m), 1383 (m), 1366 (m), 1318 (m) ), 1308 (m), 1261 (m), 1174 (m), 1092 (s), 1059 (s), 1023 (s), 911 (w), 794 (s), 717 (w), 682 (w), 666 (w), $552(\mathrm{w}), 502(\mathrm{~m}) \mathrm{cm}^{1}$.

$\mathbf{L}^{1} \mathbf{B i}\left(\mathbf{N}_{3}\right)_{2}$ 2: A suspension of $\mathrm{L}^{1} \mathrm{BiI}_{2}(1.00 \mathrm{~g}, 1.55 \mathrm{mmol})$ and $\mathrm{AgN}_{3}(2.32 \mathrm{~g}$, $15.5 \mathrm{mmol}$ ) in $50 \mathrm{~mL}$ of $\mathrm{CH}_{2} \mathrm{Cl}_{2}$ were stirred for 7 days at ambient temperature. The resulting precipitate was filtered and extracted two times with $\mathrm{CH}_{2} \mathrm{Cl}_{2}(20 \mathrm{~mL})$. The solvent was evaporated in vacuum, yielding $\mathbf{2}$ as yellow solid.

Yield $0.67 \mathrm{~g}$ (1.41 mmol, 91\%). Melting point: decomposition above $185^{\circ} \mathrm{C}$. Elemental Analysis $\mathrm{C}_{11} \mathrm{H}_{23} \mathrm{~N}_{8} \mathrm{Bi}(476.34 \mathrm{~g} / \mathrm{mol})$ : found (calcd): $\mathrm{H}$, 4.94 (4.87); C, 27.62 (27.74); N, 23.45 (23.52) \%. ${ }^{1} \mathrm{H}$ NMR (300 MHz, $\left.\mathrm{CDCl}_{3}, 25^{\circ} \mathrm{C}\right): \delta 1.31\left(\mathrm{~d},{ }^{3} \mathrm{~J}_{\mathrm{HH}}=6.2 \mathrm{~Hz}, 12 \mathrm{H}, \mathrm{CH}\left(\mathrm{CH}_{3}\right)_{2}\right), 1.58(\mathrm{~s}, 9 \mathrm{H}, t-\mathrm{Bu})$, $6.74\left(\mathrm{sep},{ }^{3} \mathrm{~J}_{\mathrm{HH}}=6.2 \mathrm{~Hz}, 2 \mathrm{H}, \mathrm{CH}\left(\mathrm{CH}_{3}\right)_{2}\right) .{ }^{13} \mathrm{C} \mathrm{NMR}\left(75 \mathrm{MHz}, \mathrm{CDCl}_{3}\right.$, $\left.25^{\circ} \mathrm{C}\right): \delta 23.9(\mathrm{CHMe}), 30.6\left(\mathrm{CMe}_{3}\right), 46.9\left(\mathrm{CHMe}_{2}\right), 52.6\left(\mathrm{CMe}_{3}\right), 177.7$ $\left(C \mathrm{~N}_{2}\right)$. IR: v 3321 (w), 3282 (w), 2971 (m) 2928 (w) 2872 (w) 2043 (s) 1992 (s), 1490 (w), 1461 (m), 1408 (s), 1384 (m), 1308 (s), 1259 (s), 1182 (m), $1115(\mathrm{~m}), 1093(\mathrm{~m}), 1044$ (s), 1028 (s), 924 (w), 864 (w), 795 (s), 705 (w), $673(\mathrm{~m}), 639(\mathrm{~m}), 596(\mathrm{w}), 555(\mathrm{w}), 477(\mathrm{w}) \mathrm{cm}^{-1}$.

$\mathbf{L}^{2} \mathbf{B i}\left(\mathbf{N}_{3}\right)_{2}$ 3. A suspension of $\mathrm{L}^{2} \mathrm{BiCl}_{2}(1.00 \mathrm{~g}, 1.43 \mathrm{mmol})$ and $\mathrm{AgN}_{3}(2.25$ $\mathrm{g}, 15 \mathrm{mmol}$ ) in $50 \mathrm{~mL}$ of $\mathrm{CH}_{2} \mathrm{Cl}_{2}$ were stirred for 7 days at ambient temperature, the resulting precipitate filtered and extracted twice with $\mathrm{CH}_{2} \mathrm{Cl}_{2}(20 \mathrm{~mL}) .3$ was obtained as yellow solid after evaporation of the solvent in vacuum.

Yield $0.94 \mathrm{~g}$ (1.32 mmol, 92\%). Melting point: decomposition above $210^{\circ} \mathrm{C}$. Elemental Analysis $\mathrm{C}_{29} \mathrm{H}_{43} \mathrm{~N}_{8} \mathrm{Bi}(712.70 \mathrm{~g} / \mathrm{mol})$ : found (calcd): $\mathrm{H}$, 6.18 (6.08); C, 48.49 (48.87); N, 15.33 (15.72) \%. ${ }^{1} \mathrm{H}$ NMR (300 MHz, $\left.\mathrm{CD}_{2} \mathrm{Cl}_{2}, 25^{\circ} \mathrm{C}\right): \delta 0.99(\mathrm{~s}, 9 \mathrm{H}, t-\mathrm{Bu}), 1.31\left(\mathrm{~d},{ }^{3} \mathrm{~J}_{\mathrm{HH}}=6.8 \mathrm{~Hz}, 12 \mathrm{H}\right.$, $\left.\mathrm{CH}\left(\mathrm{CH}_{3}\right)_{2}\right), 1.36\left(\mathrm{~d},{ }^{3} \mathrm{~J}_{\mathrm{HH}}=6.8 \mathrm{~Hz}, 12 \mathrm{H}, \mathrm{CH}\left(\mathrm{CH}_{3}\right)_{2}\right), 3.37(\mathrm{~m}, 4 \mathrm{H}$, $\left.\mathrm{CH}\left(\mathrm{CH}_{3}\right)_{2}\right), 7.13(\mathrm{~m}, 6 \mathrm{H}, \mathrm{ArH}) .{ }^{13} \mathrm{C} \mathrm{NMR}\left(75 \mathrm{MHz}, \mathrm{CD}_{2} \mathrm{Cl}_{2}, 25{ }^{\circ} \mathrm{C}\right): \delta 23.1$ $\left(\mathrm{CMe}_{3}\right), 27.4(\mathrm{CHMe}), 29.1(\mathrm{CHMe}), 29.8\left(\mathrm{CHMe}_{2}\right), 49.4\left(\mathrm{CMe}_{3}\right), 123.6$ (C4), 128.0 (C3/C5), 137.4 (C2/C6), 145.7 (N-C1), $173.3\left(\mathrm{CN}_{2}\right)$. IR: v 3340 (w), 3058 (w), 2961 (s), 2929 (m), 2869 (m), 2077 (s), 2042 (s), 2016 (s), 1999 (s), 1653 (w), 1615 (m), 1585 (w), 1436 (s), 1402 (m), 1384 (m), 1363 (m), $1318(\mathrm{~m}), 1259$ (s), $1210(\mathrm{w}), 1174(\mathrm{~s}), 1096(\mathrm{~s}), 1016(\mathrm{~s}), 970(\mathrm{w})$, 933 (w), 800 (s), 761 (s), 737 (s), 433 (m), 407 (m) cm $\mathrm{cm}^{-1}$.

Single Crystal Structure Determination of 1 - 3. Crystallographic data of 2 and 3 are summarized in Table 1. Figures $1-4$ show diagrams of the solid state structures of $\mathbf{1}-\mathbf{3}$. The crystals were mounted on nylon loops in inert oil. Data were collected on a Bruker D8 Kappa diffractometer with APEX2-detector (monochromated $\mathrm{MoK}_{\alpha}$ radiation, $\lambda=0.71073 \AA$ ) at 200(2) (1), 191(2) (2), and 100(1) (3) K. The structures were solved by Direct Methods using Bruker AXS APEX 2 software (SHELXS-97) ${ }^{20}$ and refined by full-matrix least-squares on $F^{2}$. Semi-empirical absorption corrections were applied (SADABS). All non-hydrogen atoms were refined anisotropically and hydrogen atoms by a riding model except for methyl groups which were refined as rigid groups. ${ }^{21}$ The crystals of 1 were of poor quality and showed only weak scattering power, limiting the data to $2 \theta=48^{\circ}$. Consequently, $w \mathrm{R} 2$ could not be improved below $0.25(\mathrm{R} 1=0.1)$ and substantial residual electron density remained (highest peak $3.5 \mathrm{e} / \AA^{3}$ ). The ADP of the carbon atoms did not describe a sensible thermal movement of the atoms. While not able to give a quantitatively meaningful model, the data was at least good enough to establish the connectivity of the molecule. The determined unit cell parameters are $a=16.4961(14), b=13.4902(11)$ 
and $c=31.997(3)$ in an orthorhombic lattice. 2 was refined as nonmerohedral twin using hkl 5 data. The absorption correction was performed employing TWINABS. 3 contained a disordered 1,2-difluorobenzene molecule. The final Fourier synthesis showed several peaks of $1.5-2.3$ $\mathrm{e} / \AA^{3}$. Attributing these to two $\mathrm{F}$ and six $\mathrm{C}$ atoms (their arrangement did not give a chemically sensible model) yielded a R1 of 0.0319 . Consequently, the final refinement was performed using data obtained by a PLATON/squeeze run. The squeeze refinement revealed solvent accessible at $0 / 0.5 / 0,0 / 0.5 / 0.5,0.5 / 0 / 0.5$ and $0.5 / 0 / 0$ of $424 \mathrm{e} / \AA^{3}$ each. The ADP of the dipp group bound to $\mathrm{N}(21)$ indicate either strong libration or a disorder which could not be resolved, consequently the bond length and angles are not reliable.

CCDC-864551 (2), and -864552 (3) contain the supplementary crystallographic data for this paper. These data can be obtained free of charge from The Cambridge Crystallographic Data Centre via www.ccdc.cam.ac.uk/data_request/cif.

Table 2. Crystallographic details for $\mathbf{2}$ and $\mathbf{3}$

\begin{tabular}{|c|c|c|}
\hline & 2 & 3 \\
\hline Formula & $\mathrm{C}_{44} \mathrm{H}_{92} \mathrm{Bi}_{4} \mathrm{~N}_{32}$ & $\begin{array}{l}\mathrm{C}_{116} \mathrm{H}_{172} \mathrm{~N}_{32} \mathrm{Bi}_{4} . \\
\mathrm{C}_{6} \mathrm{H}_{4} \mathrm{~F}_{2}\end{array}$ \\
\hline$M_{\mathrm{r}}$ & 1905.42 & 2964.87 \\
\hline Crystal size $\left[\mathrm{mm}^{3}\right]$ & $0.38 \times 0.12 \times 0.07$ & $0.27 \times 0.22 \times 0.13$ \\
\hline$T[\mathrm{~K}]$ & 191(1) & $100(1)$ \\
\hline Crystal system & Triclinic & monoclinic \\
\hline Space group & $P-1$ & $C 2 / c$ \\
\hline$a[\AA]$ & $10.0355(16)$ & $27.718(2)$ \\
\hline$b[\AA]$ & $12.005(2)$ & $18.2947(14)$ \\
\hline$c[\AA]$ & $14.630(3)$ & $29.720(2)$ \\
\hline$\alpha\left[^{\circ}\right]$ & $90.662(6)$ & 90 \\
\hline$\beta\left[^{\circ}\right]$ & $100.160(6)$ & $112.179(2)$ \\
\hline$\gamma\left[^{\circ}\right]$ & $102.627(6)$ & 90 \\
\hline$V\left[\AA^{3}\right]$ & $1690.6(5)$ & $13955.4(18)$ \\
\hline$Z$ & 1 & 4 \\
\hline$D_{\text {calc }}\left[\mathrm{g} \mathrm{cm}^{-3}\right]$ & 1.872 & 1.411 \\
\hline$\mu\left(\mathrm{MoK}_{\alpha}\right)\left[\mathrm{mm}^{-1}\right]$ & 10.334 & 5.086 \\
\hline Transmissions & $0.75 / 0.5$ & $0.75 / 0.44$ \\
\hline$F(000)[\mathrm{e}]$ & 912 & 5928 \\
\hline$h k l$-ranges & $\begin{array}{l}-13 \leq h \leq 12,-15 \leq k \leq 15 \\
0 \leq l \leq 18\end{array}$ & $\begin{array}{l}-29 \leq h \leq 35,-17 \leq k \leq 23, \\
-39 \leq l \leq 30\end{array}$ \\
\hline $2 \theta_{\max }\left[{ }^{\circ}\right]$ & 55 & 56 \\
\hline Reflections collected & 11364 & 99739 \\
\hline $\begin{array}{l}\text { Independent } \\
\text { reflections }\end{array}$ & 11278 & 15982 \\
\hline$R_{\mathrm{int}}$ & 0.0352 & 0.037 \\
\hline Refined parameters & 362 & 731 \\
\hline$R(F)[F \geq 4 \sigma(F)]^{\mathrm{a}}$ & 0.0298 & 0.024 \\
\hline$w R\left(F^{2}\right)(\text { all data })^{\mathrm{a}}$ & 0.0952 & 0.0498 \\
\hline $\operatorname{GoF}\left(F^{2}\right)^{\mathrm{b}}$ & 1.070 & 1.043 \\
\hline$\Delta \rho_{\text {fin }}(\max / \min )$ & $1.172 /-1.104$ & $1.001 /-0.568$ \\
\hline
\end{tabular}

$\left[\mathrm{e} \AA^{-3}\right]$

$R(F)=\Sigma|| F_{\mathrm{o}}|-| F_{\mathrm{c}}|| / \sum\left|F_{\mathrm{o}}\right| ; w R\left(F^{2}\right)=\left[\sum\left\{w\left(F_{\mathrm{o}}^{2}-F_{\mathrm{c}}^{2}\right)^{2}\right\} / \sum\left\{w\left(F_{\mathrm{o}}^{2}\right)^{2}\right\}\right]^{0,5} ; w^{-1}=$ $\sigma^{2}\left(F_{\mathrm{o}}^{2}\right)+(a P)^{2}+b P$ mit $P=\left[F_{\mathrm{o}}^{2}+2 F_{\mathrm{c}}^{2}\right] / 3, a$ and $b$ are constants chosen by program; ${ }^{\mathrm{b}} \mathrm{GoF}=\left[\sum\left\{w\left(F_{\mathrm{o}}{ }^{2}-F_{\mathrm{c}}{ }^{2}\right)^{2}\right\} /(n-p)\right]^{0,5}$ with $n$ data and $p$ parameters

Quantum Chemical Computations. Theoretical computations of structure and charge distribution of $\mathbf{2}$ were carried out at the dispersion-corrected density functional theory level (DFT+D) with the BP86 exchangecorrelation functional ${ }^{22}$ using the Turbomole V6.3 quantum chemistry program package. ${ }^{23,24}$ A quadruple-zeta valence quality (def2-QZVP) Gaussian type function basis set ${ }^{25}$ has been used to represent the orbitals along with a resolution-of-the-identity approximation of the two-electron integrals through an appropriate auxiliary basis set. ${ }^{26}$. The core electrons of the Bi atom were described through a scalar relativistiv effective core potential. ${ }^{27}$. Atomic partial charges were determined according to a natural population analysis (NPA). ${ }^{28}$

Supporting Information. CIF files giving crystallographic data for complexes $\mathbf{2}$, and $\mathbf{3}$ as well as details on the computational calculations are given in the Supporting Information File. This material is available free of charge via the Internet at http://www.eurjic.org/

\section{Acknowledgments}

Stephan Schulz gratefully acknowledges financial support by the University of Duisburg-Essen.

[1] R. Haiges, J. A. Boatz, A. Vij, M. Gerken, S. Schneider, T. Schroer, K. O. Christe, Angew. Chem. 2003, 115, 6027; Angew. Chem. Int. Ed. 2003, 42,5847 .

[2] R. Haiges, A. Vij, J. A. Boatz, S. Schneider, T. Schroer, M. Gerken, K. O. Christe, Chem. Eur. J. 2004, 10, 508.

[3] S. Schulz, B. Lyhs, G. Jansen, D. Bläser, C. Wölper, Chem. Commun. 2011, 47, 3401 .

[4] A. Schulz, A. Villinger, Chem. Eur. J. 2012, 18, 2902.

[5] B. Lyhs, G. Jansen, D. Bläser, C. Wölper, S. Schulz, Chem. Eur. J. 2011, 17, 11394 .

[6] P. Portius, P. W. Fowler, H. Adams, T. Z. Todorova, Inorg. Chem. 2008, 47, 12004.

[7] T. M. Klapötke, H. Nöth, T. Schütt, M. Warchhold, Angew. Chem. 2000, 112, 2197; Angew. Chem. Int. Ed. 2000, 39, 2108

[8] R. Haiges, J. A. Boatz, A. Vij, V. Vij, M. Gerken, S. Schneider, T Schroer, M. Yousufuddin, K. O. Christe, Angew. Chem. 2004, 116 , 6844; Angew. Chem. Int. Ed. 2004, 43, 6676.

[9] R. Haiges, M. Rahm, D. A. Dixon, E. B. Garner, III, K. O. Christe, Inorg. Chem. 2012, 51, 1127 .

[10] A. Villinger, A. Schulz, Angew. Chem. 2010, 122, 8190; Angew. Chem. Int. Ed. 2010, 49, 8017.

[11] F. Challenger, O. V. Richards, J. Chem. Soc. 1934, 405-411.

[12] J. Z. Müller, Anorg. Allg. Chem. 1971, 181, 103-115.

[13] J. Z. Müller, Anorg. Allg. Chem. 1971, 381, 103-115.

[14] P. Raj, E. Singhal, R. Rastogi, Polyhedron 1986, 5, 677-685.

[15] A. Schulz, A. Villinger, Organometallics 2011, 30, 284-289.

[16] S. Schulz, B. Lyhs, U. Westphal, D.; Bläser, R. Boese, M. Bolte, Eur. J. Inorg. Chem. 2009, 2247.

[17] a) C. Ergezinger, F. Weller, K. Dehnicke, Z. Naturforsch. 1988, 43b, 1119; b) L. A. Lesikar, A. F. Richards, J. Organomet. Chem. 2006 691,$4250 ;$ c) L. W. Pineda, V. Jancik, S. Nembenna, H. W. Roesky, Z. Anorg. Allg. Chem. 2007, 633, 2205; d) M. Brym, C. M. Forsyth, C. Jones, P. C. Junk, R. P. Rose, A. Stasch, D. A. Turner, Dalton Trans. 2007, 3282; e) S. P. Green, C. Jones, G. Jin, A. Stasch, Inorg. Chem. 2007, 46, 8; f) P. B. Hitchcock, M. F. Lappert, G. Li, A. V. Protchenko, Chem. Commun. 2009, 428.

[18] B. Lyhs, D. Bläser, C. Wölper, S. Schulz, Chem. Eur. J. 2011, 17 4914.

[19] G.-C. Guo, Q.-M. Wang, T. C. Mak, W. J. Chem. Cryst., 1999, 29, 561.

[20] G. M. Sheldrick, Acta Cryst. 1990, 46A, 467.

[21] SHELXL-97, Program for Crystal Structure Refinement, Sheldrick, G. M. Universität Göttingen, 1997. See also: G. M. Sheldrick, Acto Crystallogr. Sect. A 2008, 64, 112 and shelXle, A Qt GUI for SHELXL, C. B. Hübschle, G. M. Sheldrick, B. Dittrich, J. Appl. Cryst. 2011, 44, 1281-1284. 
[22] a) P. A. M. Dirac, Proc. Roy. Soc. (London) A 1929, 123, 714; b) J. C. Slater, Phys. Rev. 1951, 81, 385; c) S. Vosko, L. Wilk, M. Nusair Can. J. Phys. 1980, 58, 1200; d) A. D. Becke, Phys. Rev. A 1988, 38 3098; e) J. P. Perdew, Phys. Rev. B 1986, 33, 8822.

[23] TURBOMOLE V6.3 2011, a development of University of Karlsruhe and Forschungszentrum Karlsruhe GmbH, 1989-2007, TURBOMOLE GmbH, since 2007; available from http://www.turbomole.com.

[24] a) R, Ahlrichs, M. Bär, M. Häser, H. Horn, C. Kölmel, Chem. Phys. Lett. 1989, 162, 165; b) O. Treutler, R. Ahlrichs, J. Chem. Phys 1995, 102, 346; c) M. von Arnim, R. Ahlrichs, J. Chem. Phys. 1999 $111,9183$.

[25] a) F. Weigend, F. Furche, R. Ahlrichs, J. Chem. Phys. 2003, 119, 12753; b) F. Weigend, R. Ahlrichs, Phys. Chem. Chem. Phys. 2005, 7,3297 .

[26] F. Weigend, Phys. Chem. Chem. Phys. 2006, 8, 1057.

[27] B. Metz, H. Stoll, M. Dolg, J. Chem. Phys. 2000, 113, 2563.

[28] a) A. E. Reed, R. B. Weinstock, F. Weinhold, J. Chem. Phys. 1985 83,735 ; b) A. E. Reed, L. A. Curtis, F. Weinhold, Chem Rev. 1988, 88,899 .
[29] A search in the Cambridge Structural Database (CSD, Version 5.33, see also: F. H. Allen, Acta Cryst. 2002, B58, 380-388.) revealed that $\mathrm{Bi}-\mathrm{N}$ bond lengths cover a wide range from about $2.1 \AA$ to approximately $2.9 \AA$. In addition, individual distances of up to $3.3 \AA$ which is still below the sum of the van der Waals radii of $3.62 \AA$, were found. The covalent radii of $\mathrm{Bi}$ and $\mathrm{N}$ add up to $2.22 \AA$ (Pyykkö, P. Atsumi, M. Chem. Eur. J. 2009, 15, 186.) and the mean bonds length calculated from CSD data is $2.52 \AA$. Consequently, it is not always straight forward to decide whether a distance between $\mathrm{Bi}$ and $\mathrm{N}$ atoms is a covalent bond or a rather weak "attractive interaction".

[30] J. Müller, U. Müller, A. Loss, J. Lorberth, H. Donath, W. Massa, Z Naturforsch. 1985, 40b, 1320 .

Received: ((will be filled in by the editorial staff)) Published online: ((will be filled in by the editorial staff)) 


\section{Entry for the Table of Contents}

\section{Layout 1:}

Polyazides

Oligomeric Amidinatobismuth(III) diazides $\operatorname{LBi}\left(\mathrm{N}_{3}\right)_{2}$ were synthesized by metathesis reactions of the corresponding amidinatobismuth(III)dihalides with $\mathrm{AgN}_{3}$ and structurally characterized by single crystal X-ray diffraction. The bonding nature of the central azide units in the tetrameric complex $\mathbf{2}$ was investigated by theoretical calculations.

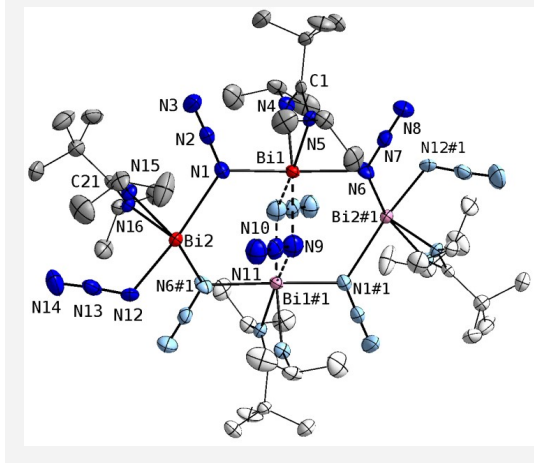

Benjamin Lyhs, Dieter Bläser, Christoph Wölper, Rebekka Haack, Georg Jansen, and Stephan Schulz* Page No. - Page No.

Structural Characterization of Amidinatobismuth(III) Diazides

Keywords: Bismuth / Amidinate / Azide / X-ray diffraction 
DuEPublico

Duisburg-Essen Publications online
DE SISEB IS R G

offen im Denken

$\mathbf{U b} \mid \begin{aligned} & \text { universitäts } \\ & \text { bibliothek }\end{aligned}$

This text is made available via DuEPublico, the institutional repository of the University of Duisburg-Essen. This version may eventually differ from another version distributed by a commercial publisher.

DOI: $\quad$ 10.1002/ejic.201200699

URN： urn:nbn:de:hbz:464-20201112-093420-3

This is the peer reviewed version of the following article: Eur. J. Inorg. Chem. 2012, 27 4350-4355, which has been published in final form at:

https://doi.org/10.1002/ejic.201200699

All rights reserved. 